\title{
Physicochemical Characterization of Sediment in Northwest Arkansas Streams
}

\author{
Chris W. Rogers ${ }^{1}$, Andrew N. Sharpley ${ }^{1}$, Brian E. Haggard ${ }^{2}$, J. Thad Scott ${ }^{1}$, Bodie M. Drake ${ }^{1}$ \\ ${ }^{1}$ Department Crop, Soil, and Environmental Sciences, University of Arkansas Division of Agriculture, Fayetteville, USA; ${ }^{2}$ Arkansas \\ Water Resources Center, University of Arkansas Division of Agriculture, Fayetteville, USA. \\ Email: cwrogers@uark.edu
}

Received March 29 $9^{\text {th }}$ 2011; revised May 2 $2^{\text {nd }}, 2011$; accepted June $10^{\text {th }}, 2011$.

\begin{abstract}
Eutrophication of surface waters is a critical concern in regions around the world facing nutrient surpluses as a result of confined animal feeding operations (CAFOs) and subsequent land application of manures. While large amounts of research exist on the transport of nutrient enriched runoff from fields to surface waters less information is available on in-stream processes controlling the transport of $P$ in-stream. Thus, information is needed on the role of stream sediments in regulating transient phosphorus $(P)$ to better understand the relationship between nutrient inputs and water quality. Fine-sized sediments $(<2-\mathrm{mm})$ regulate $P$ via sorption and burial, while algae attached to larger-sediments $(>$ 2-mm) consume and store P. From fine-sized sediment a modified P saturation ratio $\left(P S R_{m o d}\right)$, related to the sediment's ability to bind $P$ and determined from Mehlich-3 extracted nutrients, has been correlated to in-stream dissolved reactive $P(D R P)$ concentrations. The objectives of this study were to determine the relative size distribution of total- and fine-sized sediment (sand, silt clay) fractions among streams, determine the optimum sample number needed to characterize Mehlich-3 $P(M 3 P)$ and PSR ${ }_{m o d}$, and finally determine the applicability of $P S R_{\text {mod }}$ as an indicator of stream water column DRP concentrations. Stream sediments were sampled from the 0- to 3-cm depth from stream reaches ranging from $(25-75 \mathrm{~m})$ in August, 2008 for characterization along with water samples collected from the thalweg for DRP concentration determination. Additional water column samples were collected along with fine-sized sedi- ment chemical properties in February, May, and June 2009. The distribution of sediment size classes was statisti- cally similar, with 2- to 20- and 20- to 75- $\mathrm{mm}$ sized sediment dominating. Fine-sized sediment $(<2 \mathrm{~mm})$ contributed $9 \%$ to $18 \%$ of total-sediment and was comprised primarily of sand. Sampled stream M3P and PSR $R_{\text {mod }}$ were determined to typically be sufficiently characterized by a sample scheme utilizing three samples points. Modified P saturation ratio of $<2-\mathrm{mm}$ sediment was highly correlated to DRP levels across sampling dates $(r=0.86)$, suggesting PSR $R_{\text {mod }}$ has the potential to be used as an indicator of the ability of stream sediments to enrich stream water with P. Thus, fine-sized sediment nutrient concentrations appear to be key regulators of water column P concentrations.
\end{abstract}

Keywords: Stream, Phosphorus, Nutrient Enrichment, Sediment

\section{Introduction}

Accelerated eutrophication of freshwaters is identified as the leading impairment of water quality in the United States [1]. In freshwater lakes, phosphorus $(\mathrm{P})$ is linked to increased algal productivity, as it is the most common limiting nutrient for algal growth [2,3]; however, controls in stream systems can be more complex [4]. It is understood that stream sediment characteristics influence $\mathrm{P}$ types and amounts transported from the landscape to lakes and reservoirs. Within the fluvial system, sediments act as either sinks or sources of $\mathrm{P}$ and thus, may be influential in determining the time frame over which changes occur in watersheds after management strategies have been implemented [5].

Sediment size fractions have important impacts on determining dominate processes controlling P-forms in streams. Phosphorus interaction with fine-sized sediments ( $<2-\mathrm{mm})$ are typically regulated by abiotic reactions, and with increasing size, biological control associated with attached algal growth becomes the dominate $\mathrm{P}$ uptake mechanism [6]. Work in the United Kingdom reported P release from algal-biofilms on large-sized sediments (> $20-\mathrm{mm})$ to stream water was greater than release from fine sediments $(<2-\mathrm{mm})$ [7]. However, Lottig and Stanley [6] reported that fine-sediments $(<2-\mathrm{mm})$ had a greater capacity to adsorb $\mathrm{P}$ than larger sediments and thus, had 
a greater capacity to act as buffers of $\mathrm{P}$ entering during episodic rainfall-runoff events.

We determined the relative size distributions of bed sediments of five streams in the Upper Illinois River Watershed (UIRW) in Northwest Arkansas during baseflow conditions, landuse within the watershed draining into them, and sediment chemical properties using routine soil extractions. Specifically, we determined Mehlich-3 $\mathrm{P}$ and modified $\mathrm{P}$ saturation ratio ( $\mathrm{PSR}_{\mathrm{mod}}$ ), a parameter calculated from Mehlich-3 extractable nutrient concentrations of M3P and P sorbing elements [8,9]. Modified P saturation ratio was only recently reported by Haggard et al. [9] during an experiment sampling stream sediments from May to June, 2006 and thus, warrants further investigation to determine its applicability.

Specific objectives of the study were to determine the distribution of sediment proportions across streams and determine if relative proportions were similar among sampled streams, and as research constraints often pose limitations on the number of sediment samples which can be collected, we determined the optimal number of samples needed to characterize both M3P and $\mathrm{PSR}_{\bmod }$. Finally, we investigated the applicability of $\mathrm{PSR}_{\text {mod }}$ as an indicator of stream DRP concentrations across various streams and sampling dates.

\section{Methods}

\subsection{Study Site Description}

Northwest Arkansas is characterized by gently sloping hills and karst limestone geology, and was once dominated by oak (Quercus spp.) - hickory (Carya spp.) forests with areas of tallgrass prairies [10]. Within the region, these prairies have largely been converted to pasture and hay fields with poultry-beef cattle production systems dominating agricultural production. Furthermore, a large portion of the soils within the region situated atop the underlying karst limestone geology are stony, shallow, and occur on steep slopes, which can lead to rapid surface runoff and groundwater leaching [11].

Agricultural land use in Northwest Arkansas is often cited as a leading contributor to increased inputs of $\mathrm{P}$ into the waters of the region [12]. This is partly due to the rapid increase in population growth over the last 20 years and the area's large number of poultry production operations and associated litter, which is often spread on local pastures $[13,14]$. With continued application of litter at rates to meet forage nitrogen $(\mathrm{N})$ requirements, soil $\mathrm{P}$ can accumulate to levels that increase the risk of $\mathrm{P}$ enrichment of runoff [13]. Urban areas in the region are also important sources of $\mathrm{P}$, as they have large amounts of impervious surfaces, inputs from lawns, and waste water treatment plants [15]. Nutrient enrichment of surface waters from agricultural and urban sources is a worldwide phenomenon and similar issues arise in areas as diverse as Arkansas, Denmark, and Ireland [16]. These increases in CAFOs can often lead to a localized surplus of manure, and in time, can lead to the increased susceptibility of P runoff from highly P enriched surface soils $[14,16]$.

Five streams draining into the Illinois River in Northwest Arkansas were selected with agricultural, forested, and urban land uses present within each. Subwatersheds were delineated by sampling sites using a digital elevation model and land use/land cover data in ArcGIS 9.2 [17-19]. The delineated subwatersheds were determined using the ArcHydro tool within ArcGIS and proportion land use was calculated as percentages of total land area within each subwatershed.

\subsection{Sample Collection and Analysis Techniques}

A representative reach (riffle and pool) was identified at each of the 5 streams in August, 2008. Reaches (25 - 75 $\mathrm{m})$ were measured at equally spaced intervals with 7 to 10 transects collected to determine the relative substrate composition of the streams. As sediment distribution and characterization was a primary objective at the August, 2008 sample date, each individual transect was collected separately. Transect width was measured and stream velocity measured using a Flo-Mate 2000 (Marsh-McBirney, Inc., Frederick, MD) at equally spaced points across the individual transects upstream at each sampling site during baseflow conditions. Width and velocities were used to calculate flow rate and average velocity across each transect within the reach.

At each site, a stream water sample was collected from the thalweg at the time of sediment sampling. A water subsample was filtered $(0.45-\mu \mathrm{m})$, acidified to $\mathrm{pH} 2(\mathrm{HCl})$ in-field, and transported to the laboratory and stored at $4^{\circ} \mathrm{C}$ until analysis. An unfiltered water sample was also acidified (pH 2) and stored at $4^{\circ} \mathrm{C}$ until analysis. Filtered samples were analyzed for DRP using the automated ascorbic acid method on a Skalar San Plus Wet Chemistry Autoanalyzer (Skalar, the Netherlands) [20]. The total P (TP) concentration of unfiltered samples was determined after digestion via an alkaline persulphate method [21,22].

A $2 \mathrm{~L}$ sample of total-sediment was collected from a 0 - to 3-cm depth at five locations across each transect with a spade and composited to create a representative sample. Samples from the transect were sieved to size classes of $>75,75$ to 20, 20 to 2, and $<2$-mm within 24 $\mathrm{h}$ after sampling. A $<2$-mm sample of sediment was collected at 5 locations along each transect and composited for subsequent particle size analysis and a sub-sample air dried prior to determination of Mehlich-3 extractable 
nutrients. Each size fraction of sediment was air dried. After drying, size classes were measured using a standard water displacement procedure, where water $(6 \mathrm{~L})$ was added to a container and the volume of water displaced measured when each size class was added. Total displacement of all size classes was determined along each transect and each size class divided by this total to determine relative proportion of each size class within the stream transect.

Particle-size distribution of the fine-fraction sediment $(<2-\mathrm{mm})$ was determined by the hydrometer method [23]. Sediments were added at $50 \mathrm{~g}$ dry weight to a $1 \mathrm{~L}$ cylin- der with $50 \mathrm{~mL}$ of sodium hexametaphosphate and brought to volume. Three hydrometer readings were taken and averaged at the $40 \mathrm{~s}$ mark, and one $2 \mathrm{~h}$ reading was taken. These reading were then used to calculate the relative proportion of sand $(2-0.05-\mathrm{mm})$, silt $(0.05$ $0.002-\mathrm{mm})$, and clay $(<0.002-\mathrm{mm})$ at each transect within each stream. Mehlich-3 extractable $\mathrm{P}$ of the fine-fraction was determined by shaking $1 \mathrm{~g}$ air-dried sediment with $10 \mathrm{~mL}$ mixture of $0.2 \mathrm{M} \mathrm{CH}_{3} \mathrm{COOH}, 0.25$ $\mathrm{M} \mathrm{NH}_{4} \mathrm{NO}_{3}, 0.015 \mathrm{M} \mathrm{NH}_{4} \mathrm{~F}, 0.013 \mathrm{M} \mathrm{HNO}_{3}$, and 0.001 $M$ EDTA end-over-end for 5 min [8]. Mehlich-3 extracts were centrifuged (2 $500 \mathrm{~g}$ for $10 \mathrm{~min}$ ) and filtered $(0.45$ $\mu \mathrm{m}$ ) prior to determining P, Fe, Mg, Mn, and Ca [8]. Determination of the mini- mum sample number necessary to describe Mehlich-3 P and PSR mod within the sample stream reaches were determined based on individual transect determination of Mehlich-3 $\mathrm{P}$ and PSR $_{\text {mod }}$ from the August, 2008 sample date.

To investigate the relationship between $\mathrm{PSR}_{\bmod }$ and DRP concentrations in stream water, a composite fine sized sediment $(<2-\mathrm{mm})$ sample from the previously identified transects and water column samples for DRP were conducted three additional times (February, May, and June 2009). As stream sediments had been characterized by the initial August, 2008 sampling, the relationship between fine-sized sediment chemical properties across sampling dates was determined on a single composite sample from each stream in August, 2008, February, May, and June 2009.

\subsection{Modified Phosphorus Saturation Ratio}

Mehlich-3 P has been used as an indicator to estimate the potential for soil P release to runoff [24,25]. In Sims et al. [26], P saturation ratio (PSR) was determined from Mehilich-3 extractable elements as PSR $=[\mathrm{M} 3 \mathrm{P} / \mathrm{M} 3 \mathrm{Al}+$ M3 Fe]. This ratio includes P-reactive trace elements and improves upon the relationship between soil test $\mathrm{P}$ measures and subsequent DRP concentrations of surface runoff, as increases in these trace elements decrease the movement of P into the water column [26]. For calcareous soils, inclusion of M3Ca and M3Mg improved the relationship between PSR and runoff DRP [27]. Haggard et al. [9] modified the $\mathrm{P}$ saturation ratio $\left(\mathrm{PSR}_{\mathrm{mod}}\right)$ to [M3P / M3Fe + M3Mg + M3Mn] for calcareous streams. Modified P saturation ratio was found to be statistically more closely correlated to in-stream DRP concentrations $(r=0.71)$ than M3P alone $(r=0.50)$ in Haggard et al. [9]. As only a limited sampling period was used to determine $\mathrm{PSR}_{\text {mod }}$ [9], the current research will further investigate the effectiveness of the parameter in predicting DRP concentrations in stream water at different times and locations.

\subsection{Statistical Analysis}

Linear regressions were performed in SigmaPlot with significance levels of $\alpha<0.05$. Regressions of largesized sediment and DRP are constructed from composited sediment values at individual streams and sampled DRP concentrations from the August, 2008 sampling date. Composited fine-sized sediment samples from four sample dates (August 2008, February, May, and June 2009) are used for the regressions focusing on the finesized sediment chemical parameters of Mehlich-3 P and $\mathrm{PSR}_{\text {mod. }}$. Relationship strength between parameters within the text is discussed in terms of correlation coefficients $(r)$. When regression models are presented in figures coefficients of determination $\left(\mathrm{R}^{2}\right)$ are reported.

To determine if differences in sediment distribution existed among streams, a one-way analysis of variance (ANOVA) was performed in SAS 9.2. Transects of the August, 2008 sampling date were used as replicates and streams treated as fixed factors and the four size classes and three $<2$-mm size classes tested separately. When stream effect was significant, means were separated using Fisher's protected least significant difference (LSD). Differences in sample number $(n)$ for this analysis are based on the number of equally spaced transects measured at individual sites.

For the samples collected in August, 2008 at individual transects, M3P and PSR $_{\text {mod }}$ were tested in a multiple step procedure to determine the minimum number of samples necessary to quantify M3P and $\mathrm{PSR}_{\text {mod }}$. The procedure for this analysis was conducted as follows, first the sample means were calculated from the entire set of sampled transects at each site and treated as the "true" mean. Given the restriction of end samples always being taken for each possible sample size, a complete enumeration of all possible samples for a given size (e.g., sample size 5) were generated, and 95\% confidence intervals (C.I.) were constructed using a standard T-statistic. The number and percentage of samples in which the confidence interval contained the "true" mean was calculated. The smallest sample size for which the percentage of samples within the $95 \%$ confidence interval was equal to 
or greater than 95\% was deemed sufficient to be used for sampling of that parameter. In this analysis $n$ refers to individual transects from each site.

A second ANOVA was performed for samples collected at the four sampling dates. Both water column P concentrations and chemical parameters associated with the fine-sized sediment were compared across streams. In this analysis, an overall composite from the August, 2008 sampling date was used along with the additional sampling dates of February, May, and June 2009. These sampling dates constitute four replications and within the analysis, stream was treated as a fixed factor and DRP, $\mathrm{pH}, \mathrm{M} 3 \mathrm{P}, \mathrm{M} 3 \mathrm{Ca}, \mathrm{M} 3 \mathrm{Fe}, \mathrm{M} 3 \mathrm{Mg}, \mathrm{M} 3 \mathrm{Mn}$, and $\mathrm{PSR}_{\mathrm{mod}}$ were tested separately. Parameters which had a significant stream effect were subsequently separated using Fisher's protected least significant difference (LSD). Composite samples were used for this analysis and therefore, $n$ in this analysis refers to the sampling dates of August 2008, February, May, and June 2009.

\section{Results and Discussion}

\subsection{Land Use}

Stream sites within the region represented varying land uses and within each site, agricultural, forested, and urban activities were present (Figure 1). Mud Creek Tribu-

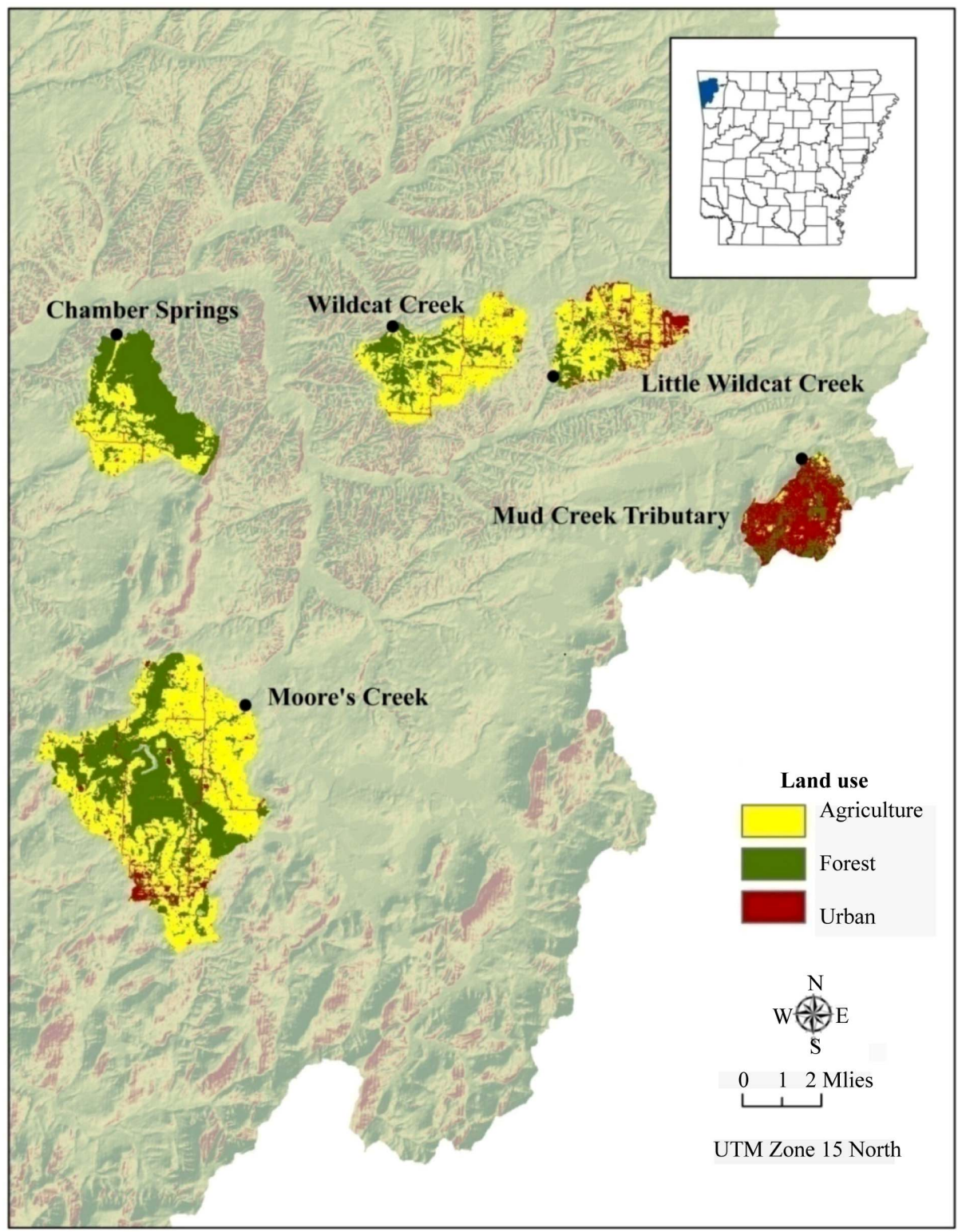

Figure 1. Map of delineated research site drainage basins with land use land classification (agriculture, forest, urban) for five streams in the Upper Illinois River Watershed, AR. 
tary had the most urbanized subwatershed of those studied with $68 \%$ of the drainage area dominated by this land use and only 7\% composed of agricultural land (Table 1). In contrast, Wildcat Creek was nearly 70\% agriculture and $4 \%$ urban. Chamber Springs with $61 \%$ forest was the only primarily forested landscape; however, the watershed is also comprised of 38\% agriculture much of which is directly adjacent to the stream (Table 1). Finally, Moore's Creek was comprised mainly of agriculture and forested land with $56 \%$ and $39 \%$ of the total land area in the land uses respectively.

\subsection{Stream Flow and Velocity (August, 2008)}

Average stream velocity at the time of stream characterization (August, 2008) was variable across sites, ranging from 0.06 to $0.26 \mathrm{~m} \cdot \mathrm{s}^{-1}$ (Table 2). Decreased sediment/ water interaction time in higher velocity streams has been cited as decreasing $\mathrm{P}$ uptake in streams, and since these streams were all at baseflow conditions it appears likely $P$ retention time within streams will be impacted by velocity and that faster moving streams will have less time to interact with transient $\mathrm{P}$ [28]. The current study had slightly higher velocities overall than those reported by D’Angelo et al. [28] from North Carolina streams (0.04 $0.17 \mathrm{~m} \cdot \mathrm{s}^{-1}$ ). As all subsequent sampling times (February, May, and June 2009) were conducted during baseflow conditions, it is likely that sediment water interactions

Table 1. Percentage of watershed in agriculture, forest, and urban land use categories for five selected streams in the Upper Illinois River Watershed, AR.

\begin{tabular}{lccc}
\hline Stream & Urban (\%) & $\begin{array}{c}\text { Agriculture } \\
\text { (\%) }\end{array}$ & $\begin{array}{c}\text { Forest } \\
\text { (\%) }\end{array}$ \\
\hline Chamber Springs & 1 & 38 & $61^{*}$ \\
Little Wildcat Creek & 19 & 61 & 20 \\
Mud Creek Tributary & 68 & 7 & 25 \\
Moore's Creek & 6 & 56 & 39 \\
Wildcat Creek & 4 & 70 & 26 \\
\hline
\end{tabular}

"Percentages in italics represent the major land use with a give stream watershed.

Table 2. Water column parameters including Dissolved Reactive $P$ (DRP) and Total $P$ (TP) concentrations for five selected streams in the Upper Illinois River Watershed, AR in August, 2008.

\begin{tabular}{ccc}
\hline Stream & Velocity $\left(\mathrm{m}^{3} \cdot \mathrm{s}^{\mathbf{- 1}}\right)$ & Flow rate $\left(\mathrm{m}^{3} \cdot \mathrm{s}^{-1}\right)$ \\
\hline Chamber Springs & 0.20 & 0.08 \\
Little Wildcat & 0.26 & 0.16 \\
Moore's Creek & 0.12 & 0.20 \\
Mud Creek Tributary & 0.06 & 0.02 \\
Wildcat Creek & 0.20 & 0.19 \\
\hline
\end{tabular}

in these streams are decreased even more during high velocity events such as during high rainfall, and nutrient transport to overlying waterbodies and that $\mathrm{P}$ transport is elevated at those times.

Flow rates also varied across streams and ranged from 0.02 to $0.20 \mathrm{~m}^{3} \cdot \mathrm{s}^{-1}$ (Table 2). Thus, varying transient storage times across sites occurred, which may lead to differences in $\mathrm{P}$ uptake due to water-sediment residence time differences. For example, Mud Creek Tributary is likely to have flashy events where water levels rise rapidly due to the high percentage of urban land within the watershed and thus, during these events markedly decreased interaction with stream bed sediment is likely to occur.

\subsection{Sediment Distributions (August, 2008)}

The relative size distribution of total sediment classes was determined in August, 2008 and was similar across sites with no statistical differences to report. Based on volumetric displacement, the $>20$-mm sized sediment accounted for roughly $50 \%$ of bed sediment across all sites (Table 3). Gainswin et al. [7] reported chlorophylla concentrations of 2- to 20 -mm size fraction sediment at two sampled sites in the United Kingdom (6.4 and 8.6 $\mathrm{mg} \cdot \mathrm{m}^{-2}$, respectively) was appreciably lower than $>20$ mm sediment ( 22.8 and $62.7 \mathrm{mg} \cdot \mathrm{m}^{-2}$, respectively). Sediment of 2- to 20-mm cholorophyll-concentrations were more similar to fine sediments, which had chlorophyllconcentrations of 3.0 and $2.3 \mathrm{mg} \cdot \mathrm{m}^{-2}$, respectively [7]. The intersection of these size classes likely represents an important transition from abiotic to biotic dominance of $P$ reactions and transformations. Thus, bed sediments of streams in the UIRW represent a system in which there are large portions of sediment where $P$ reactions are predominately biologically driven ( $>20-\mathrm{mm})$ and large portions which are abiotically driven $(<20-\mathrm{mm})$.

Further separating the size classes, the $>75-\mathrm{mm}$ sediments comprised the lowest percentage across sites, ranging from $0.3 \%$ to $10.8 \%$ of bed sediment (Table 3 ). The $<2$-mm sediments were the second lowest, ranging from $9 \%$ to $18 \%$ of streambed composition. However, < 2-mm sediments are likely to have the largest surface area per unit weight of any sediment size class and thus, greatest chemical reactivity. The $75-$ to $20-\mathrm{mm}$ and $20-$ to 2 -mm classes represented roughly 80 to $90 \%$ of the total bed material across sites and ranged from 35 to 48 and $36 \%$ to $46 \%$ of fluvial sediment, respectively. No significant differences between streams for any size class was observed; $p$-values ranged from 0.188 (20 to $2 \mathrm{~mm}$ ) to 0.534 ( $<2 \mathrm{~mm})$, thus, means were not separated by Fisher's Protected LSD (Table 3).

At the time of sampling, in-stream concentrations of DRP decreased as the percentage of $>75-\mathrm{mm}$ sediment 
Table 3. Sediment size classifications and < 2-mm particle size analysis for five selected streams in the Upper Illinois River Watershed, AR in August, 2008.

\begin{tabular}{|c|c|c|c|c|c|c|c|c|}
\hline \multirow{2}{*}{ Stream } & \multirow[b]{2}{*}{$n$} & \multicolumn{4}{|c|}{ Total Sediment (mm) } & \multicolumn{3}{|c|}{$<2$-mm particle size } \\
\hline & & $>75$ & $75-20$ & $20-2$ & $<2$ & Sand & Silt & Clay \\
\hline & \multicolumn{5}{|c|}{$\%$} & \multicolumn{3}{|c|}{$\%$} \\
\hline Chamber Springs & 9 & 5.7 & 45.5 & 36.6 & 12.2 & $85.5 b *$ & $9.2 \mathrm{a}$ & 5.3 \\
\hline Little Wildcat Creek & 8 & 10.8 & 40.4 & 40.3 & 8.6 & $92.0 \mathrm{ab}$ & $5.6 a b$ & 2.4 \\
\hline Moore’s Creek & 9 & 0.3 & 35.0 & 46.2 & 17.9 & 90.9ab & $3.8 \mathrm{~b}$ & 5.3 \\
\hline Mud Creek Tributary & 10 & 12.2 & 40.4 & 36.2 & 11.2 & $94.8 \mathrm{a}$ & $3.1 \mathrm{~b}$ & 2.1 \\
\hline Wildcat Creek & 9 & 7.4 & 48.7 & 35.7 & 14.3 & $84.7 \mathrm{~b}$ & $9.8 \mathrm{a}$ & 5.4 \\
\hline Standard Error $(n=10)$ & & 3.4 & 4.1 & 3.3 & 3.9 & 2.5 & 1.4 & 1.2 \\
\hline Standard Error $(n=9)$ & & 3.6 & 4.3 & 3.5 & 3.9 & 2.6 & 1.5 & 1.3 \\
\hline Standard Error $(n=8)$ & & 3.8 & 4.6 & 3.7 & 4.1 & 2.8 & 1.6 & 1.3 \\
\hline$p$-value & & $0.200^{* *}$ & 0.220 & 0.188 & 0.534 & 0.048 & 0.008 & 0.145 \\
\hline
\end{tabular}

increased (Figure 2). Total $\mathrm{P}$ concentrations also decreased when the percentage of $>75$-mm sediment increased (Figure 2). This is likely related to associated periphyton growth on large sediments (> 20-mm) acting as sinks of $\mathrm{P}$ during growth and uptake. However, upon death and decomposition, algal biomass can become a source of $P$ to overlying waters [29].

\subsection{Fine-Fraction Sediment (August, 2008)}

The percentage of $<2$-mm sized sediment was greatest at Moore's Creek and represented $18 \%$ of the total bed substrate whereas, Little Wildcat Creek had the least fine-sized sediment at $9 \%$. Across streams, there was no significant stream effect ( $p=0.534$ ) on the mean $<2$-mm percentage (Table 3). However, significant differences were apparent in the $<2$-mm size class fractions (sand, silt, clay). Sand (0.05- to 2-mm) was the most predominant fraction of $<2$-mm sediment, comprising over $80 \%$ of the fine sediment at each site (Table 3). Differences in the size of the sand fraction existed among streams, with Mud Creek Tributary having a significantly greater mean sand content than either Chamber Springs or Wildcat Creek (Table 3). This fraction is often linked to highly available P-fractions which are less tightly sorbed than on clay-sized fractions, and thus, Mud Creek Tributary likely has less $\mathrm{P}$ binding capacity during high input events than Wildcat Creek or Chamber Springs.

The silt-sized fraction was also variable within sites and across streams. Both Wildcat Creek and Chamber Springs had a statistically greater mean silt-sized fraction than Mud Creek Tributary (Table 3). The clay-fraction was not statistically different among streams $(p=0.145)$, but within sites ranged from $2.1 \%$ to $5.4 \%$ (Table 3 ). While clay-fractions typically can hold the most $\mathrm{P}$, this is also contingent on the extent and duration of $\mathrm{P}$ inputs to
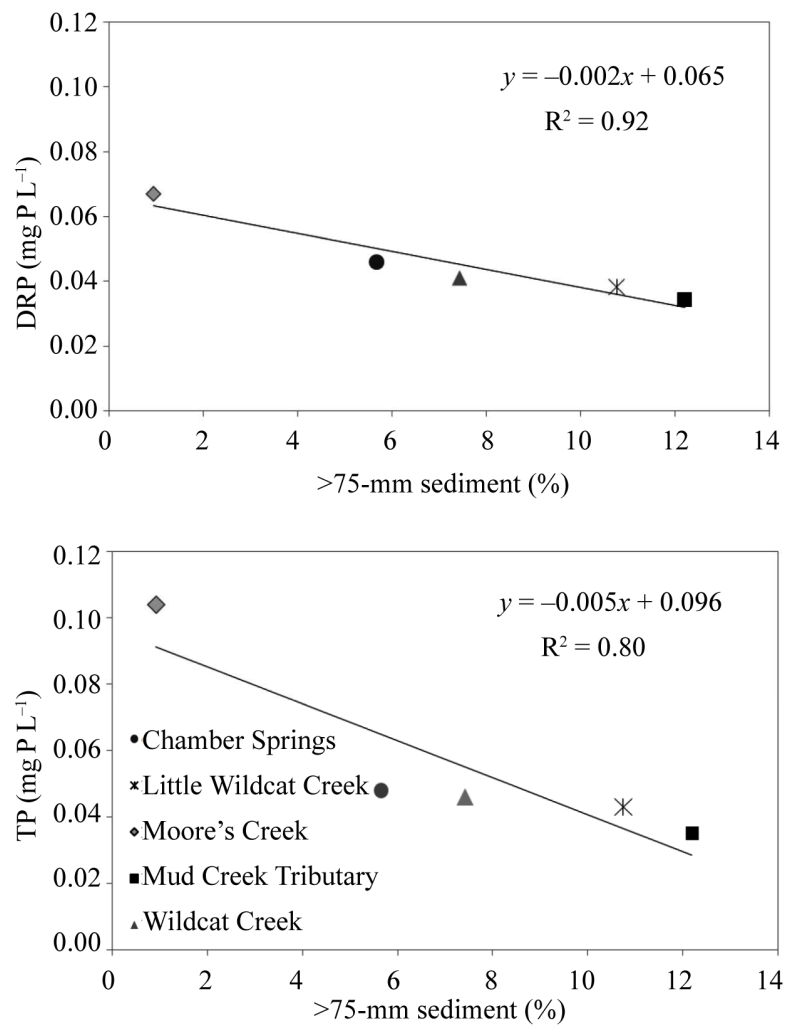

Figure 2. Relationship between Dissolved Reactive $\mathbf{P}$ concentration (DRP) Total $P$ (TP) and average percent > 75-mm sediment at five streams in the Upper Illinois River Watershed, AR. 
the stream. Similar to results from McDowell and Sharpley [30], our site with the greatest percentage of land area as forest (Chamber Springs) had relatively high clay content (5.3\%) (Table 3) and the lowest M3P concentration, true mean, (Table 4) compared to the other sites. This is likely due to a lack of $\mathrm{P}$ inputs to forested areas and subsequent $\mathrm{P}$ runoff to the stream. Also, $\mathrm{P}$ held by sand-sized particles is generally less tightly sorbed than to clay-sized particles and is more easily released to water [6]. While percent sand was statistically different among sites, its general predominance (84.7\% - $94.8 \%$ ), and the fact that the mean clay content across sites was statistically similar led to the lack of statistically significant correlations between $<2$-mm fractions and $\mathrm{P}$ concentrations.

While the relative distribution of size classes in streams plays a role in in-stream $\mathrm{P}$ transport, it appears that the concentration of nutrients transported to the stream and sorbed by fine-sized sediment can be quite variable even in streams with similar stream bed compositions. This is likely due to the continued replenishment of fine-sized sediment from the landscape in turn acting as a renewal mechanism for $\mathrm{P}$ within these stream sites. For example, Mud Creek Tributary, which drains a highly urbanized area, experiences rapid influxes of water during storm events, thus, sediments may be more rapidly transported within this stream than those draining dominantly agricultural or forested areas. Subsequently, these large loads can continually replenish its sand-sized fraction (95\%) and the remainder of the $<2$-mm size fraction of bed sediment with eroded soil [31]. In contrast, Moore's Creek a predominately agricultural and forested site is likely less influenced by rapid changes in velocity and thus, water column sediment interactions are a more dominant force, particularly as M3P concentrations within this stream are higher than any other stream sampled (Table 4).

\subsection{Minimum Sample Number (August, 2008)}

Previous work in the region focusing on $\mathrm{P}$ in fluvial sediments, has sampled three transects within a stream reach [9]. The current study collected 8 to 10 transect sediment samples from each stream reach (Table 4). The study reach lengths and total sample number were variable across streams ( 26 - $69 \mathrm{~m}$ ), because of differences in accessibility and geomorphology. Thus, if we assume the more rigorous sampling protocol of the current study precisely characterized Mehlich-3 extractable nutrient concentrations of the benthic sediments using these multiple transects then we could evaluate the minimum number of transects needed to characterize M3P. Based on the five sampled streams, the minimum number of transects needed for 95\% coverage of the 95\% confidence interval of the "true" mean of M3P at the sites sampled was generally three (Table 4). The exception was at Wildcat Creek where 4 samples were needed. For $\mathrm{PSR}_{\text {mod }}$ the trend was similar except Wildcat Creek required 5 samples to cover the confidence interval. The issue at Wildcat Creek is that the site had a larger amount of variation within as illustrated by the large standard errors (Table 4). Thus, when sites are sampled, careful attention to the insite variability is likely a clue as to whether a set of 3 samples is sufficient to adequately describe the sampled stream reach, and if large variation exist a larger sample number would be recommended.

\subsection{Mehlich-3 Content of Fluvial Sediments (August 2008, February, May, and June 2009)}

The Mehlich-3 P concentrations of $<2$-mm sediments ranged from 13 to $39 \mathrm{mg} \cdot \mathrm{P} \cdot \mathrm{kg}^{-1}$ (Table 5). It appears that sediment M3P was highly correlated to DRP $(r=0.86)$, with increased streambed M3P content leading to greater stream DRP concentrations (Figure 3). This relationship is stronger than previously reported for this region by Haggard et al. [9; $r=0.50$ ], but with a similar slope (0.0016 compared to the prior 0.0022). However, as our relationship between M3P and stream DRP is driven by one high-P site (Moore's Creek), we further investigated $\mathrm{PSR}_{\text {mod }}$ as a more accurate parameter for correlating

Table 4. Stream length and minimum number of samples needed to represent reach sediment Mehlich-3 P (M3P) and Modified P Saturation Ratio (PSR mod $_{\text {) }}$.

\begin{tabular}{|c|c|c|c|c|c|c|c|c|}
\hline \multirow[b]{2}{*}{ Stream } & \multirow[b]{2}{*}{$n$} & \multirow{2}{*}{$\begin{array}{l}\text { Reach } \\
\text { Length }\end{array}$} & \multicolumn{3}{|c|}{ Mehlich-3 P } & \multicolumn{3}{|c|}{ PSRmod } \\
\hline & & & $\begin{array}{l}\text { "True } \\
\text { Mean" }\end{array}$ & $\begin{array}{c}\text { Standard } \\
\text { Error }\end{array}$ & $\begin{array}{c}\text { Mean Sample Size for } \\
\text { 95\% C.I. }\end{array}$ & $\begin{array}{l}\text { "True } \\
\text { Mean" }\end{array}$ & $\begin{array}{c}\text { Standard } \\
\text { Error }\end{array}$ & $\begin{array}{c}\text { Mean Sample } \\
\text { Size for } 95 \% \text { C.I. }\end{array}$ \\
\hline & & $\mathrm{m}$ & $\mathrm{mg} \cdot \mathrm{P} \cdot \mathrm{kg}^{-1}$ & & Sample number & $\%$ & & Sample number \\
\hline Chamber Springs & 9 & 45 & 11.5 & 1.32 & 3 & 5.1 & 0.44 & 3 \\
\hline Little Wildcat Creek & 8 & 26 & 16.9 & 1.93 & 3 & 5.0 & 0.43 & 3 \\
\hline Mud Creek Tributary & 10 & 69 & 13.7 & 1.59 & 3 & 3.3 & 0.36 & 3 \\
\hline Wildcat Creek & 9 & 38 & 15.6 & 2.17 & 4 & 4.0 & 0.66 & 5 \\
\hline
\end{tabular}


Table 5. Mehlich-3 nutrients, Modified $P$ Saturation Ratio $\left(\mathrm{PSR}_{\mathrm{mod}}\right)$, and $\mathbf{p H}$ of sediments from five selected streams in the Upper Illinois River Watershed, AR from sampling dates in August 2008, February, May, and June 2009.

\begin{tabular}{|c|c|c|c|c|c|c|c|}
\hline Stream & $n$ & DRP & pH & МЗР & МЗСа & M3Fe & PSRmod \\
\hline & & $\mathrm{mg} \cdot \mathrm{P} \cdot \mathrm{L}^{-1}$ & & & $\mathrm{mg} \cdot \mathrm{P} \cdot \mathrm{kg}^{-1}$ & & $\%$ \\
\hline Chamber Springs & 4 & $0.410 b^{*}$ & $7.5 \mathrm{~b}$ & $13 c$ & $1221 c$ & $156 b$ & $4.7 b$ \\
\hline Little Wildcat Creek & 4 & 0.029cd & 7.7ab & 15bc & $825 d$ & $124 b$ & $4.8 \mathrm{~b}$ \\
\hline Moore's Creek & 4 & $0.074 \mathrm{a}$ & $7.4 \mathrm{~b}$ & $39 a$ & $730 \mathrm{~d}$ & $358 a$ & $7.8 \mathrm{a}$ \\
\hline Mud Creek Tributary & 4 & $0.021 d$ & $8.1 \mathrm{a}$ & $13 c$ & $1878 b$ & $165 b$ & $2.7 \mathrm{c}$ \\
\hline Wildcat Creek & 4 & $0.035 b c$ & $8.1 \mathrm{a}$ & $19 b$ & $2805 a$ & $162 b$ & $4.6 b$ \\
\hline Standard Error & & 0.004 & 0.2 & 2 & 113 & 17 & 0.4 \\
\hline$p$-value & & $<0.0001$ & 0.02 & $<0.0001$ & $<0.0001$ & $<0.0001$ & $<0.0001$ \\
\hline
\end{tabular}

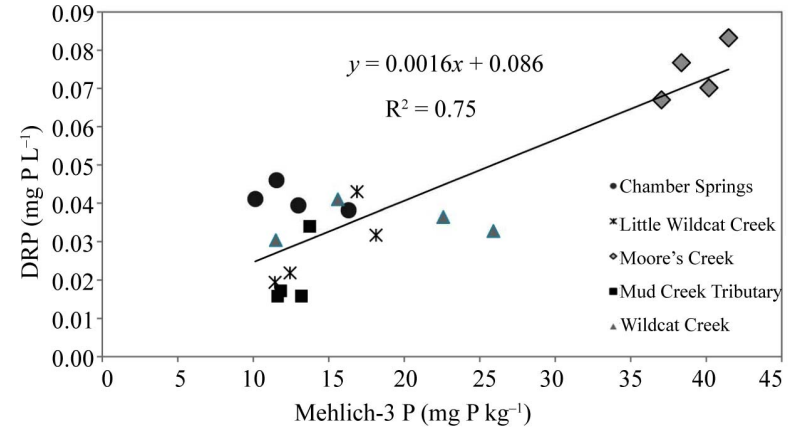

Figure 3. Relationship between average Mehlich-3 P (M3P) and Dissolved Reactive $P$ concentrations (DRP) for five streams in the Upper Illinois River Watershed, AR.

streambed chemical characteristics to overlying water column DRP concentrations. Because sediment P availability is influenced by P-sorbing elements and the relationship between M3P and DRP concentrations is problematic due to the influence of Moore's Creek, PSR $_{\text {mod }}$ was utilized.

Calculated PSR $_{\text {mod }}$ ranged from $3 \%$ to $7.8 \%$ across sites and may be a better indicator of $\mathrm{P}$ availability as it considers $\mathrm{Fe}, \mathrm{Mg}$, and $\mathrm{Mn}$ concentrations, which influence $\mathrm{P}$ sorption and regulate $\mathrm{P}$ availability to the water column (Table 5). Across sites, PSR $_{\text {mod }}$ for Moore's Creek sediment was the highest at $7.8 \%$ and statistically different from the remaining sites. Mud Creek Tributary sediment was the lowest PSR $_{\text {mod }}(2.7 \%)$ and was statistically different from the other sites. Chamber Springs, Little Wildcat Creek, and Wildcat Creek sediments have similar PSR $_{\text {mod }}$ values (Table 4). When analyzed across sampling dates, Modified P saturation ratio was highly correlated to stream DRP concentrations $(r=0.86)$ with a slope of 0.0096 (Figure 4). The slope of the PSR $\mathrm{mod}_{\mathrm{mod}}$ and stream DRP relationship in this study is approximately two times that (0.004) found by Haggard et al., [9], indicating DRP concentrations in some streams may be controlled by fine-sized sediment nutrient concentrations and may thus, have a greater impact on stream DRP concen-

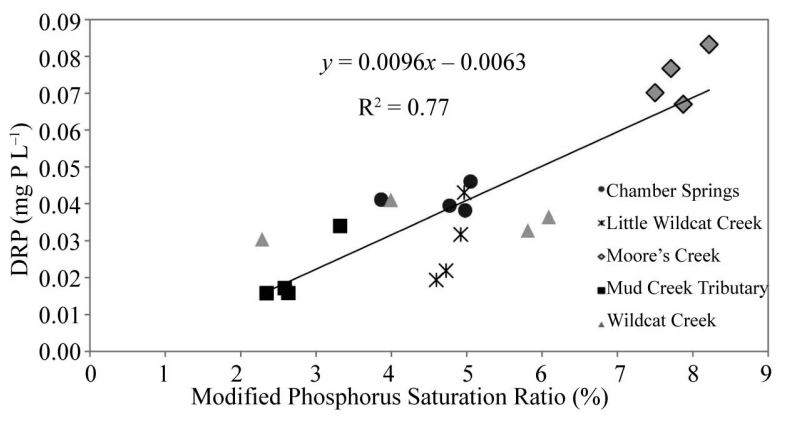

Figure 4. Relationship between Modified P Saturation Ratio $\left(\mathbf{P S R}_{\text {mod }}\right)$ of sediments and Dissolved Reactive $\mathbf{P}$ concentrations (DRP) for five streams in the Upper Illinois River Watershed, AR.

trations.

Based on the work of Lottig and Stanley [6] and our results, it is probable that PSR $_{\text {mod }}$ decreases with increasing amounts of larger-sized sediments and may be representative of a shift in the buffering mechanisms from abiotic to biotic control. Thus, in terms of P transformations between stream sediments and the water column, it is important to consider the concentrations of trace elements as well as P. Differences in P-chemistry across streams is likely due to other factors than simple sediment particle size distribution, as they are comparable in their relative percentages (Table 3). Other factors such as $\mathrm{P}$ input source, biological uptake, clay mineralogy, sediment $\mathrm{P}$ concentrations, differences in $<2$-mm sediment and $\mathrm{P}$ inputs to the stream from the landscape will be important in determining $\mathrm{P}$ transformations and transport in these streams.

\section{Conclusions}

It is apparent that many variables contribute to determining the DRP concentration of stream water at any point in time. Across streams large-sized sediments (> 20-mm) were highly correlated to DRP and TP concentrations, because attached algae can act as temporary $\mathrm{P}$ storage mechanisms. As our sampled sites have a large portion of 
the substrate composed of larger-size fractions, biofilm growth is likely a key regulator of DRP concentration. Further research concerning biological uptake in these streams is warranted to encompass all mechanisms which may be of importance to $P$ transport within these watersheds. Fine-sized sediment characteristics within streams were relatively similar with sand predominating at all sites; however, differences were apparent in the M3P concentration of specific streams. Thus, simple substrate composition determination of fine-sized sediments does not implicitly determine the concentration or controls $\mathrm{P}$ in stream sediments. Three transects appear sufficient (in most instances) as a sampling strategy adequate to measure mean M3P and PSR $_{\text {mod }}$ content of fine-sized sediments in Northwest Arkansas streams and those with similar characteristics. However, if large variations in M3P and PSR $_{\text {mod }}$ exist, it is likely more samples are

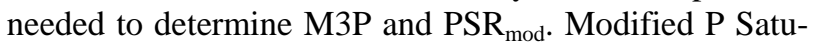
ration Ratio was recently described by Haggard et al. [9] as predictor of DRP concentrations in stream water. The current research was conducted at different locations and times than the earlier work and found strong correlation between PSR $_{\text {mod }}$ and stream DRP concentrations and thus, enhances the utility of PSR $_{\text {mod }}$ for varying times and locations. Further, investigations focusing on $\mathrm{PSR}_{\text {mod }}$ will enhance the understanding of its adaptability to other sites and locations. Sediment is important in regulating water column $\mathrm{P}$ and thus, in determining $\mathrm{P}$ transport to lakes and reservoirs of the region. These findings in streams of the UIRW provided an exceptional area to investigate nutrient enrichment in a region in which both urban and agricultural sources operate alongside one another. These findings can be expanded to streams with similar physicochemical compositions, particularly in regions where nutrient enrichment from agricultural sources such as CAFOs are of importance.

\section{Acknowledgments}

The authors wish to give special thanks to Jason Corral, Tony Zambrano, Stephanie Williamson, Josh Romeis, and Tarra Simmons for assistance in field collection and lab analysis. Also, thanks to Dr. Edward Gbur of the University of Arkansas Agricultural Statistics Laboratory for his help in experiment design and data analysis. Funding was provided by the Arkansas Water Resources Center through a USGS 104-B grant.

\section{REFERENCES}

[1] United States Environmental Protection Agency, "Environmental indicators of water quality in the United States,” 1996, EPA 841-R-96-002.

[2] R. Howarth and H. Paerl, "Coastal Marine Eutrophication: Control of both nitrogen and phosphorus is necessary,"
Proceedings of the National Academy of Sciences of the United States of America, Vol. 105, No. 49, 2008, p. E103. doi:10.1073/pnas.0807266106

[3] D. Schindler, R. Hecky, D. Findlay, M. Stainton, B. Parker, M. Patterson, K. Beaty, M. Lyng and S. Kasian, "Eutrophication of lakes cannot be controlled by reducing nitrogen inputs: Results of a 37-year whole-ecosystem experiment," Proceedings of the National Academy of Sciences of the United States of America, Vol. 105, No. 32, 2008, pp. 11254-11258. doi:10.1073/pnas.0805108105

[4] W. Dodds, "Trophic state, eutrophication and nutrient criteria in streams," Trends in Ecology \& Evolution, Vol. 22, No. 12, 2007, pp. 669-676. doi:10.1016/j.tree.2007.07.010

[5] R. McDowell, A. Sharpley and A. Chalmers, "Land use and flow regime effects on phosphorus chemical dynamics in the fluvial sediment of the Winooski River, Vermont,” Ecological Engineering, Vol. 18, No. 4, 2002, pp. 477-487. doi:10.1016/S0925-8574(01)00108-2

[6] R. Lottig and E. Stanley, "Benthic sediment influence on dissolved phosphorus concentrations in a headwater stream,” Biogeochemistry, Vol. 84, No. 3, 2007, pp. 297-309. doi:10.1007/s10533-007-9116-0

[7] B. Gainswin, W. House, B. Leadbeater, P. Armitage and J. Patten, "The effects of sediment size fraction and associated algal biofilm on the kinetics of phosphorus release," Sciences of the Total Environment, Vol. 360, No. 1-3, 2006, pp. 142-157. doi:10.1016/j.scitotenv.2005.08.034

[8] A. Mehlich, "Mehlich-3 soil test extractant: A modification of Mehlich 2 extractant," Communications in Soil Science and Plant Analysis, Vol. 15, No. 12, 1984, pp. 1409-1416. doi:10.1080/00103628409367568

[9] B. Haggard, D. Smith and K. Brye, "Variations in stream water and sediment phosphorus among select Ozark catchments," Journal of Environmental Quality, Vol. 36, No. 6, 2007, pp. 1725-1734. doi:10.2134/jeq2006.0517

[10] K. Brye and C. West, "Grassland management effects on soil surface properties in the Ozark Highlands," Soil Scienc, Vol. 170, No. 1, 2005, pp. 63-73. doi:10.1097/00010694-200501000-00008

[11] G. Brion, K. Brye, B. Haggard, C. West and J. Brahanna, "Land-use effects on water quality of a first-order stream in the Ozark Highlands, Mid-Southern United States," River Research and Applications. doi:10.1002/rra.1394

[12] T. Sauer, P. Moore, J. Ham, W. Bland, J. Prueger and C. West, "Seasonal water balance of an Ozark hillslope," Agricultural Water Management, Vol. 55, No. 1, 2002, pp. 71-82. doi:10.1016/S0378-3774(01)00185-8

[13] A. Sharpley, S. Herron and T. Daniel, "Overcoming the challenges of phosphorus-based nutrient management in poultry farming," Journal of Soil and Water Conservation, Vol. 62, No. 6, 2007, pp. 375-389.

[14] N. Slaton, K. Brye, M. Daniels, T. Daniel, R. Norman and D. Miller, "Nutrient input and removal trends for agricultural soils in nine geographic regions in Arkansas," Journal of Environmental Quality, Vol. 33, No. 5, 2004, 
pp. 1606-1615. doi:10.2134/jeq2004.1606

[15] S. Ekka, B. Haggard, M. Matlock and I. Chaubey, "Dissolved phosphorus concentrations and sediment interactions in effluent-dominated Ozark streams," Ecological Engineering, Vol. 26, No. 4, 2006, pp. 375-391. doi:10.1016/j.ecoleng.2006.01.002

[16] R. Maguire, G. Rubaek, B. Haggard and B. Foy, "Critical evaluation of mitigation of options for phosphorus from field to catchment," Journal of Environmental Quality, Vol. 38, No. 5, 2009, pp. 1989-1997. doi:10.2134/jeq2007.0659

[17] Center for Advanced Spatial Technology (CAST), “Arkansas Land Use and Land Cover,” 2006. http://www.geostor.arkansas.gov/G6/Home.html

[18] Environmental Systems Research Institute, “ArcGIS 9.2,” Redlands, 2006.

[19] Arkansas State Land Information Board (ASLIB), "2006 5-Meter Resolution Digital Elevation Model,” 2007, http://www.geostor.arkansas.gov/G6/Home.html

[20] American Public Health Association (APHA), "Standard Methods for the Examination of Water and Wastewater," 20th Edition, Washington, DC, 1998.

[21] M. Hosomi and R. Sudo, "Simultaneous determination of total nitrogen and total phosphorus in freshwater samples using persulphate digestion," International Journal of Environmental Studies, Vol. 27, No. 3-4, 1986, pp. 267-275. doi:10.1080/00207238608710296

[22] D. Lamber and W. Maher, "An evaluation of the efficiency of the alkaline persulfate digestion for the determination of total phosphorus in turbid waters," Water Research, Vol. 1, No. 1, 1995, pp. 7-9. doi:10.1016/0043-1354(94)00141-S

[23] M. Arshad, B. Lowery and B. Grossman, "Physical Tests for Monitoring Soil Quality,” In: J. W. Doran and A. J. Jones, Eds., Methods for Assessing Soil Quality. Soil Science Society of America, Madison, 1996, pp. 123-141.
[24] A. Sharpley, T. Daniel, J. Sims and D. Pote, "Determining environmentally sound soil phosphorus levels," Journal of Soil and Water Conservation, Vol. 51, No. 2, 1996, pp. 160-166.

[25] P. Vadas, P. Kleinman and A. Sharpley, "Relating soil phosphorus to dissolved phosphorus in runoff: A single extraction coefficient for water quality modeling," Journal of Environmental Quality, Vol. 34, No. 2, 2005, pp. 572-580. doi:10.2134/jeq2005.0572

[26] J. Sims, R. Maguire, A. Leytem, K. Gartley and M. Pautler, "Evaluation of Mehlich-3 as an agri-environmental soil phosphorus test for mid-Atlantic United States of America,” Soil Science Society of America Journal, Vol. 66, No. 6, 2002, pp. 2016-2032. doi:10.2136/sssaj2002.2016

[27] D. Ige, O. Akinremi and D. Flaten, "Environmental index for estimating the risk of phosphorus loss in calcareous soils of Manitoba," Journal of Environmental Quality, Vol. 34, No. 6, 2005, pp. 1944-1951. doi:10.2134/jeq2004.0468

[28] D. D’Angelo, J. Webster and E. Benfield, "Mechanisms of stream phosphorus retention: an experimental study," Journal of the North American Benthological Society, Vol. 10, No. 3, 1991, pp. 225-237. doi:10.2307/1467596

[29] P. McCormick, R. Shuford and M. Chimney, "Periphyton as a potential phosphorus sink in the Everglades Nutrient Removal Project," Ecological Engineering, Vol. 27, No. 4, 2006, pp. 279-289. doi:10.1016/j.ecoleng.2006.05.018

[30] R. McDowell and A. Sharpley, "Uptake and release of phosphorus from overland flow in a stream environment," Journal of Environmental Quality, Vol. 32, No. 3, 2003, pp. 937-948. doi:10.2134/jeq2003.0937

[31] A. Sharpley, S. Chapra, R. Wedepohl, J. Sims, T. Daniel and K. Reddy, "Managing agricultural phosphorus for protection of surface waters: issues and options," Journal of Environmental Quality, Vol. 23, No. 3, 1994, pp. 437-451. doi:10.2134/jeq1994.00472425002300030006x 